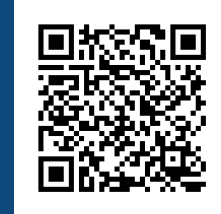

Keywords:

Development

Law

Public interest

Forests

Sustainability

Historic:

Received 29/06/201 8

Accepted 14/12/2018

Correspondence:

ggencay@bartin.edu.tr

Üstüner Birben', Gökçe Gençay²+

\title{
PUBLIC INTEREST VERSUS FORESTS
}

BIRBEN, U.; GENÇAY, G. Public interest versus forests. CERNE, v. 24, n. 4, p. 360-368, 2018.

\section{HIGHLIGHTS}

Development priorities can alter sustainable forest management via the concept of public interest.

Forests should be considered under the concept of "superior public interest".

Public interest concept for forest policy should be determined by subjective criteria.

\section{ABSTRACT}

This article analyses role of the concept of "public interest" in forest management, governance and conservation in Turkey and seeks to obtain an insight into the "public interest" through exploring the permit process given by the State, and to help better understanding the roots of current issues. An institutional approach will be followed and various formal and informal legislation will be explored in their complex and dynamic interplay, which leads and shapes practices on the ground and resulting outcomes. The purpose of this paper is to bring some new perspectives to the debate about the proper balance between economic development policies and forest protection. It is also hypothesized that the concept of "public interest" could increase and lead deforestation through legislation. It first explains the theoretical framework on resource management, forest policy, and public interest. This general overview is followed by a more in-depth analysis of the role that public interest plays in deforestation via the permit process in the State forests. Turkey has lost irrevocably an area of 654.833 hectares in the State forests via the 94.148 permits granted. This analysis of public interest confirms that it is important to avoid legislation that overreaches. The concept of public interest may exceed implementation capacity (i.e., there may be an imbalance between the activities, procedures and institutional arrangements prescribed by legislation and high court decisions). Re-organization of decision-making mechanisms/process with a more participative approach is an important step toward achieving good governance and sustainability of the forest resources. 


\section{INTRODUCTION}

Although humanity has progressed during the past 10,000 years, no single people or culture has been immune from experiencing cycles of improving prosperity, technological and institutional changes have provided the means for a general improvement in the human condition (Dalton et al., 2005). Furthermore, over the past few decades, changing social values combined with developments in ecological sciences, environmental and ecological economics, law, and other fields have led to the identification and justification of new claims for public intervention in private land-use decisions and for reconsideration of existing uses of public lands (Haddad, 2003).

The environment is not external to the human being. We utilize from and depend on their capacity and health. What distinguishes us from environment is our capacity to shape our environment (Kant and Barry, 2005). Through the 1970s, 1980s, and 1990s, and have if anything intensified as the realities of the climate change issue have begun to dawn, the issue of global environmental sustainability has loomed and environmental sustainability has increasingly become the watchword (Douglas and Simula, 2010). Raised global concerns about the sustainability of natural and human systems. The role of forest resources and sustainable forest management in sustainable development can be gauged from the fact that forest resources are a critical component of most of the sustainability (Kant and Barry, 2005). Maintaining sustainability does not mean that forests should be left untouched (Landsberg and Waring, 20I4). Sustainable management of forest resources poses one of the world's greatest challenges (Tucker, 1999). Forestry is one of the few land use sectors that involve very long time periods in commodity production. Decision-makers in forest policy and practice have to make long-term choices affecting generations (Zivnuska, 1949; Price, 1989). In the past, forestry development was considered within the rural modernisation perspective, and attention was focused on the primary production function of forests as a means to contribute to rural livelihoods by providing products for home consumption (e.g. fuelwood), income and employment (Wiersum et al., 2005). Changes in meanings and perceptions of forests over the last century have suggested that there is a dynamic relationship between humankind and forests (Owubah, et al., 200I). The decline in biodiversity is a major concern in contemporary society. Forest ecosystems warrant special attention since these are both hosting a large fraction of existing species and are under particular threats - e.g., conversion into arable land or construction, unsustainable logging practices, fragmentation (Vatn, 2005). The idea of a green economy appears to try and balance the need for economic growth while having the least impact on the environment, which would seem to be an offshoot of the previously popular term 'sustainable development' (Edward and Kleinschmit, 20I3). It would be reasonable to suggest that concern for resource sustainability and environmental protection should have remained high on the public debate agenda globally (Douglas and Simula, 2010).

The forests are a multiple-use resource where both economic and ecological goals can be achieved in the same forest area (Anthon et al., 2010). The relationship between human beings and forests has been important for the development of society (Ritter and Dauksta, 20I3). Forests are critical to the daily survival of hundreds of millions of people (Seymour and Forwand, 2010). The fears are mainly for the services and intangible benefits that forests provide, rather than the timber supplies or other material goods derived from forest (Gane, 2007). Like most natural resources, equitably across regions and countries, forest governance and regulation has always mirrored other developments of the time (Srivastava, 20II). The focus of much of the research on forest resources and governance is on the relationship between forest tenure and resource sustainability (Jagger et al., 20I4). Yet, there is an emerging debate in the fields of environmental and natural resources law regarding interactions between policy tools (Nie, 2008). In many countries with significant remaining natural forest cover, the political economy of forest management involves complex and often competing social, political, and economic interests. Weak forest governance structures include inappropriate forest law, weak law enforcement capacity may hinder the sustainable forest management (Seymour and Forwand, 2010). Thus, depending on its political and economic implications, forest policy can be either of low (e.g. if talking about forest biodiversity) or high such relevance (Giessen et al., 2014). In addition to that, regulatory instruments are the classical instruments of politics that are used to solve social or economic conflicts. In evaluating regulatory instruments, it thus highly depends on correctly assessing the power of legal authority (Krott, 2005). To sustain long-term use of renewable resource systems like forests, collective action is needed to limit resource use and to undertake various forms of active management (Poteete and Ostrom, 2004). Therefore, in general, the real problem of ecosystem governance is really to whom can we trust the responsibility for the ecosystem functioning and 
the sustainable provision of ecosystem services. The increasing resource complexity, the increasing fuzziness of the nature of the goods, and the changing roles for the state represent a challenging backscreen for the introduction of adaptive ecosystem governance both in the European Union and in the UN family of nations (Sandberg, 2007).

Taken together, the first and perhaps the most heatedly debated question in this paper is that does the concept of public interest can play a negative role in forest protection. Because, public interest focuses on reshaping public policy and affects the interests of a substantial population (Cummings, 20I5). No papers have conducted an analysis that the public interest can play a negative role in forest protection and sustainable use of forest resources such as that which we carry out in this study. To accomplish this, our analysis focus on three research questions: What is the main characteristics of permits related to the State forests in Turkey? Why the governments with a vested interest try to open the State forests for alternative uses? Why the judiciary is so involved in forest policy and law? These are important forest policy issues/questions focused on public interest in Turkey including how strictly public interest criteria should be enforced, and to what extent public interest should be clarified and limited to be able to mitigate the forest degradation and deforestation. It is also hypothesized that high levels of involvement on state forests via public interest will be associated with higher forest degradation and deforestation.

\section{FOREST POLICY AND PUBLIC INTEREST}

Adoption and implementation of sustainable forestry practices are essential for sustaining forest resources, yet development of effective policies and strategies to achieve them are problematic (Owubah, $200 \mathrm{I})$. Governments have a legitimate role in regulating and administering land rights, due to the significance of land in the economy, people's livelihoods and employment, and the stability of the nation (Toulmin, 2009). Forest policy is public policy and is a segment or subset of public policy. In many countries, particularly among the developing nations, governments directly control large areas of forestland, which is owned by the State. Too often, the policy-making procedure has been bureaucratic and 'top down', with national aims formulated by the government ministry responsible for forestry (Mantau, et al., 2007). It is clear that "command and control" approaches to conservation can be poorly suited and political decision makers whom often favor less adversarial approaches to resource management (Nie, 2008). Changing forest governance today is a move away from centrally administered, top-down regulatory policies that characterized much of the 19th and 20th centuries (Agrawal et al., 2008). In addition to that, obviously, the legislation governing access to public forests, and the constraints placed on industrial operations, vary from country to country (Landsberg and Waring, 20I4). The role of the state and its bureaucracies must not be underestimated (Peters, 20I I).

The bulk of policies in forestry are aimed for supporting sustainable forest management, wood production and ecological services of the forests rather than entrepreneurship as such. It appears that in forest policy, entrepreneurship has often not been even a primary issue of concern or emphasis, despite its high importance in the societies in general (Niskanen et al,, 2007). The hopes and expectations of both those who utilize the forest and those who protect it are put forward to the state, in particular, as the central political force (Krott, 2005). Because, promoting the implementation of national and international forest-related commitments, policies and goals towards sustainable forest management means having to understand and adjust to the needs of thousands or millions of individuals, households and micro-enterprises (Rametsteiner, 2009). These finding are quite straightforward in the case of Turkey too. The state forests play an important role in the ecological environment development, timber production and land security. Forestry legislation was largely developing in the wake of general economic and political movements rather than within a special pathway in Turkey. Because the lack of knowledge of the forest services has been under increasing pressure to return money to the general fund (Hansis, 1998).

Environmental legislation is fundamentally concerned with the limitation or redistribution of property rights in this sense - as elements of utility - in order to pursue a public policy objective in environmental protection (Rodgers, 2009). The problem with authoritarian solutions to environmental (and economic) problems is that even if they succeed for long periods, they create hidden resentments that ultimately endanger their achievements (Henleyn, 2008). In relation to our study, we can add to these, overreaching tends in forest law, such as provisions exceeding implementation capacity, reasonable and legitimate objectives, and provisions socially acceptable (MacKenzie, 20I2).

The origin of the public interest comes most directly from the notion of counter-balancing the 
influence of powerful economic interests in the legal system, and regardless of their objective (Rekosh, 2005). The public interest, as the term is usually employed, is taken to comprise the ultimate ethical goal of political relationships, and institutions and practices are to be judged desirable or undesirable to the extent that they contribute to or detract from the realization of the public interest (Cassinelli, 1958). Although the term "public interest" is a central concept to a democratic system of government, it has never been definitively defined either in legislation or by the courts. Academics have also been unable to give the term a clear and precise definition. While there has been no clear interpretation, there has been general agreement in most societies that the concept is valid and embodies a fundamental principle that should guide and inform the actions of public officials (Wheeler, 2006). In addition to that, there is no single formula, which works in every situation when it's come to speak about public interest. It is certainly undeniable that there are still differences of views among states concerning which interests should be regarded as public interests, how they should be institutionalized, and how they should be implemented (Komori, 2007). It is important to have a clear understanding of the "public interest" which is also a complex phenomenon. The idea that a "public interest" can be identified has been problematic, at least since Glendon Schubert's work more than four decades ago. The uncertain meaning of public interest allows it to be used to justify individual or group preferences or undemocratic use of public power and its fuzziness makes it awkward as a practical guide to daily affairs (Box, 2007). Among the various criticisms advanced, several seem incontestable: (a) the term is vague and ambiguous, (b) individual authors are not consistent in their usage of the term, (c) many concepts of the public interest are virtually indistinguishable from more general concerns of morality, and (d) there have been few efforts to measure the public interest, none entirely successful (Bozeman, 2007). Essentially the question of whether public interest is the main problem, or the main solution, for both the sustainable forest management and forest protection. It is to be expected that the efficient use of resources to accomplish goals will be an important concern in government at the micro, operational level, but efficiency at the operational level has become confused with broader matters of governing. The idea of a public interest can be crucial (Box, 2007).

\section{TURKEY'S FORESTS AND PUBLIC INTEREST}

Turkey has 22.3 million hectares forest, of which $56 \%$ is productive, and approximately, $28,6 \%$ of its land area is covered by forests (OGM, 2015). Forestry has traditionally been of high social importance both to forest villagers and to whole population in Turkey. Since 1937, the Turkish forestry has been shaped as a top-down control-and-command system. However, the Turkish forest management system has inherited a few but very crucial elements of the Ottoman era in the sense of forest ownership. The state is still the owner of the percentage of the forests $(99,98 \%)$ in Turkey (Forest Law, 1956, Article 4) and forestry planning is administered by state's itself for the forest management. For decades, the main state body of forest management have been always the General Directorate of Forestry (GDF) starting from 1839. GDF was the state administration responsible for organization of forest use, management, regeneration and protection, as well as interaction of state forest agencies with the local people.

Policy on forest management and governance has been largely a matter of national responsibility in Turkey since 1937. Nationalization, taking public interest as a base, in 1945 by the Law No 4785 brought all forestlands, other than all trees planted on private lands according to the Forest Law No. 3116 of 1937, under state ownership. Excessive arson occurred from the end of the 1945 to the late 1947. Indeed, in the first two years after the law has entered into force, 290.422 ha of forest area had burned in 2.092 forest fires (Birben, 2008). Turkey never actually stopped making efforts at formulating and adjusting forest laws and regulations in seeking a balance between forest use and conservation since then.

The control over forests was further emphasized by successive legislation, including both the $196 \mathrm{I}$ and 1982 Constitutions. According to the constitutional provisions of the article 131 of $196 \mid$ Constitution and article 169 of 1982 Constitution still in force: State forests cannot be subject to easement except for public interest. This statutory provision also shows its effect in the Forest Law. There are four main permits subject to easements in the Forest Law. It should be immediately noted that easements have a complex structure. It is difficult to understand and interpret these rights due to the variety and the extensiveness of its contents. When the rights unite with Forest Law, the situation faced is very hard to comprehend completely (Coşkun, 1999). The permits are used to allocate the State forests to other uses are: article 16 related to Mining; article 17 related to Developments; article 18 related to Treasure search, Archaeological excavation and Restoration; Pits; Factory, Sawmill, Strip; Fish farming facilities. According to the statistics of the GDF, until the beginning of 2017, 94. 148 permits were granted in an area of 654.833 hectares in the State forests (OGM, 2012; OGM, 20I7). 
TABLE I Granted permits in the State Forests.

\begin{tabular}{ccc}
\hline Years & Quantity & Area (ha) \\
\hline Pre-2012 & 64.069 & 465.518 \\
2012 & 5.145 & 20.746 \\
2013 & 5.371 & 38.301 \\
2014 & 7.704 & 40.937 \\
2015 & 5.698 & 46.938 \\
2016 & 6.122 & 42.393 \\
Total & 94.109 & 654.833 \\
\hline
\end{tabular}

Especially the Article 17 has also been subject to decisions of the constitutional court and has been amended many times in the Parliament. Since 1956, the date of the first entry into force of the Forest Law, Article 17 has been amended four times by Law No. 5192 in 2004, Law No. 600I in 2010, Law No. 6292 in 2012 and Statutory Decree No. 694 in 2017. In particular, the constitutional court's decision dated I7.I2.2002 and numbered 2002/200 is related to the public interest. In that decision, it is stressed and emphasized that "The necessity of considering and evaluating the concept of public interest separately in every single case has been left aside. Thus, the usage of forestlands secured by the Constitution is ended/opened up to any kind of utilisations. It is essential for the forestlands to be subject to easement only if the conditions that there is an indispensability/necessity for the facilities or enterprises to be in the forests. Article 169 of the Constitution provides detailed arrangements for the protection and improvement of forests, with due regard to the importance of forests for the country. There is no doubt that this particular and detailed arrangement is needed due to the fact that the country's forest cover has been destructed constantly. It is clearly stated in the first paragraph of the Article that the State shall adopt the necessary legislation for the protection of forests and the expansion of its areas, and shall take measures to ensure that the observance of all forests belongs to the State. In the second paragraph, it is stated that the ownership of the State forests cannot be transferred; State forests will be managed and operated according to the laws by the State; these forests cannot be acquired by prescription and cannot be subject to easements other than public interest. In the third paragraph, it is stated that no activities and actions damaging forests shall be allowed. It is mentioned in Article 7 of the Constitution "legislative authority on behalf of the Turkish Nation belongs to the Grand National Assembly of Turkey and this authority is not transferable". However, without drawing any scope regarding with the conditions of the public interest and excluding the constitutionally protected and prohibited areas in accordance with the first sentence of the third paragraph of Article 17 of the Forest Law, the Ministry of Forestry may grant permission to real and legal persons with a fee. This means that only the public interest would be sufficient for the allotment of the forestlands. Thus, due to the fact that the boundaries of the concept have not been determined and the framework has not been drawn, the administration has been granted a very wide margin of appreciation. The allotment of the forestlands to the real and legal persons should be limited to cases where priority public services such as roads, telephone, electricity, water, gas, oil pipelines, defence facilities, sanatoriums etc. are required, and there is a necessity for the facilities or enterprises to be in the forests. In other words, the easement can only be established on the State forests if there is a public interest and necessity. On the other hand, when it is taken into account that the forests are under protection of the Article 169 of the Constitution, it is necessary to determine/draw by the law what conditions the public interest concept that mentioned/ specified in this article covers. Without considering that, just by leaving the administration to determine the scope and content of the concept in question does not comply with the principle of ineligibility of the legislative authority." Hereby, the main question is why the article has to be amended so often? The answer is simple; the State forests cover almost a quarter of the country's surface and it is the cheapest source of land for the investments necessary for economic development. This is better understood when the historical process of amendments is examined. According to Article 17/3 of Forest Law; if

TABLE 2 Type of Developments in Forest Law.

\begin{tabular}{|c|c|}
\hline $\begin{array}{l}\text { First version of the } \\
\text { Article I7 } \\
\text { (of 1956) }\end{array}$ & $\begin{array}{l}\text { Amendment version of the Article } 17 / 3 \\
\text { (of 2017) }\end{array}$ \\
\hline $\begin{array}{l}\text { ny kind of buildings and } \\
\text { stallations for general } \\
\text { ealth, safety and } \\
\text { enefit aesthetically } \\
\text { touristic forest } \\
\text { roduct producers and } \\
\text { sers }\end{array}$ & $\begin{array}{l}\text { A Defence, } \\
\text { Transport, } \\
\text { Energy, } \\
\text { Communication, } \\
\text { Water, } \\
\text { Wastewater, } \\
\text { Oil, } \\
\text { Natural gas, } \\
\text { Infrastructure, } \\
\text { Solid waste disposal and landfill } \\
\text { facilities } \\
\text { B) Barrage, } \\
\text { Pond, } \\
\text { Street animals nursing homes } \\
\text { and cemeteries } \\
\text { C) State-owned } \\
\text { Health, } \\
\text { Education, } \\
\text { Judicial service } \\
\text { Sports facilities and penal execution } \\
\text { Institutions and all kinds of grounds and } \\
\text { buildings related to them }\end{array}$ \\
\hline
\end{tabular}


there is the public interest and necessity for those king of developments to be built and installed in the State forests, the real and legal persons may be allowed/granted at a fee by the Ministry of Forestry and Water Affairs. No fees shall be charged from the State-owned and/or operated ones. Permit period can not last more than forty-nine years. In the end of the permit period, all kinds of buildings and facilities other than those constructed by the State are transferred to the GDF in full and free of charge. Such facilities can be used in the need of the GDF or the Ministry of Forestry and Water Affairs or can be evaluated by giving to the rent. Permit periods for the beneficiaries operating in accordance with the terms and conditions in a given permit can be extended up to 99 years with an annual price to be determined on the basis of fair value of land, buildings and facilities. Granted permissions can not be used except for purpose. Table 2 shows that how comprehensive the changes (type of developments) are.

Despite the use of general expressions/ definitions/terms in the Article 17/3, even more detailed facility/installations/structures were mentioned in the regulation named "Implementing Regulation of the Articles 17/3 and 18 of the Forest Law". Table 3 shows the detailed list of those developments.

TABLE 3 Type of Developments in the State Forest in the Forest Regulation.

\begin{tabular}{|c|c|}
\hline Main categories & Developments \\
\hline Defence & $\begin{array}{l}\text { explosive safety area, underground explosive } \\
\text { storage, defence and security facilities }\end{array}$ \\
\hline Transport & $\begin{array}{l}\text { roads, port back service areas, airports, } \\
\text { railways, cable car lines, tunnels etc }\end{array}$ \\
\hline Energy & $\begin{array}{l}\text { power transmission lines, transformer } \\
\text { buildings, power generation plants, } \\
\text { measurement and observation stations etc }\end{array}$ \\
\hline Communication & $\begin{array}{l}\text { telephone transmission line, communication } \\
\text { panel, measurement station, R/L facilities, radio- } \\
\text { television transmitting station and antennas, } \\
\text { base stations of electronic communication } \\
\text { systems, fiber optic cable facilities etc }\end{array}$ \\
\hline Water & $\begin{array}{l}\text { water explorations, geothermal weldings and } \\
\text { natural mineral water exploration, water wells, } \\
\text { catchments, water lines, water storages etc }\end{array}$ \\
\hline Oil & oil and natural gas pipelines \\
\hline Infrastructure facility & $\begin{array}{l}\text { solid waste transfer station, solid waste } \\
\text { disposal and landfill facilities, facilities for oil } \\
\text { and natural gas exploration, operation and } \\
\text { underground natural gas storage based on } \\
\text { permits, underground storage facilities }\end{array}$ \\
\hline $\begin{array}{c}\text { Barrage, Pond, Street } \\
\text { animals nursing homes } \\
\text { and Cemeteries }\end{array}$ & $\begin{array}{l}\text { Barrages, Ponds, Street animals nursing } \\
\text { homes and cemeteries }\end{array}$ \\
\hline $\begin{array}{c}\text { Health } \\
\end{array}$ & health centres, hospitals etc \\
\hline Education & $\begin{array}{l}\text { primary, secondary, high school and religious } \\
\text { education facilities, religious place of worships etc }\end{array}$ \\
\hline Sport & $\begin{array}{l}\text { football fields, indoor sports halls, shooting } \\
\text { ranges etc }\end{array}$ \\
\hline
\end{tabular}

The first question that comes to mind is who is authorized to determine conditions of both the "public benefit" and "necessity" in the permit process? Probably the first thing people will come up with is top-level board of experts from related permit fields. Answer is simply, "No". According to Article 3/J of the Regulation mentioned above, there is only a commission consisting of at least three members--Under a chairman of the Deputy Regional Directorate of Forestry or the branch manager or the engineer or the related Vice Forest District Directorate; a related Vice Forest District Directorate; a related chief of the Forest Sub-district Directorate, if available a chief of the Forest Cadastre and Ownership and / or a technical staff--all of them are forest engineer appointed by GDF. Even the spatial dimension/area and the level of expertise required for different development types to be taken into consideration solely, it is obvious that the commission will be inadequate. At this point, the structure of the commission needs to be improved. At least an expert from related permit topic; relevant nongovernmental organizations; universities; and local people should be included in this decision-making process.

\section{DISCUSSION AND CONCLUSION}

Institutions are regarded as man-made social constructions that regulate the relations between humans themselves with regard to the use of certain resources, while the biophysical attributes of a particular resource are considered given and unaffected by the institutional arrangements. In the vast literature on relationships between fundamental institutions and the governing of resources, the dominant paradigm has been that property rights matter (Sandberg, 2007). At this point, the concept of "public interest", which restricts property rights when conditions are met and keeps community/public benefit superior, is important. What is immediately noticeable from and about the "public interest" is how it plays a primary and vicious role by shaping the forest policy and law in Turkey. Decisions made in the near future via the "public interest" will be critical in determining the types of development that shape governance and management of the State forests and their sustainability in Turkey. In the longer term, however, the political priorities underlying such decisions can be expected to shift with the changing demands and needs of the society and national economic agenda. In other words, the behaviour of government in forestryrelated decisions via the public interest is influenced by what is national interest. 
When discussing the various bonds between public interest and legislation, it becomes clear that many of them have changed through time. In addition, conceptual and practical problems exist on the public interest. Even if the characteristics of public interest are clearly defined, the concept of public interest will require clarification and to be re-assessed in every original/single situation throughout the permit process over the State forests in Turkey. Unfortunately, while government continue to exercise rogue one size fits all public interest criteria's that are to be applied for any permits in the State forests, It would be reasonable to suggest that concern for sustainable forest management should have remained on the public debate agenda.

A process-based public interest may not offer permanence and certainty, but in a particular place and time the people involved in a public decision-making process can reach a conclusion about the public interest that has a significant effect on governing, on the way government action impacts people and the social or physical environment. Designing appropriate forms of "public interest" to delineate boundaries and limit the powers of the GDF in this respect therefore constitutes an important step toward achieving good governance and sustainability, but considerable debate exists over the form of public interest most likely to result in with no common ground.

The effectiveness of decision-making process of the public interest will depend on a number of factors, including public participation and true nature of permits. This may require long-term economic, institutional, political, and social change but without such the protection/use balance is not fully achieved, this change is unlikely to begin. Ultimately, high court decisions and their characteristics are key factors to be able to define the boundaries of the public interest along with the legislation related to permits.

There is a danger that focusing narrowly on the conceptual framework and limits of public interest would have a negative impact on SFM via the conversion of forests for other land use systems. The most obvious direct impact of that process is to irrevocable loss of forest. The irony here is that while the concept of public interest was the main driving force of the forest protection in 1960s and ' $80 \mathrm{~s}$ in Turkey, the concept became a negative tool for influencing the forests and forest policies under the influence of national economic development since then. The public interest may actually lead, in some cases, to deforestation because of its nature that it is an ill-defined, contradictory, or inconsistent concept. Second, economic policies for development may have negative impacts on forests as well. Because, according to new institutional economics, institutions are 'the rules of the game' (North, 1990).

The concept of public interest is a concept that used by administrative jurisdictions to supervise the work and operations of the governmental administrative organizations as a basic criterion when conducting judicial audits. The Constitutional Court has come to define public interest as "ensuring peace and prosperity of the person and the society". The use of the public interest concept as a public benefit in the constitutional judgment and the academic environment is widespread. The Council of State has used and preferred the concept of "superior public interest" by creating a concept of jurisprudence in situations where public interest raises (Gül, 20l4).

Any activity within forest areas is to be faced with making a very important decision about the future of the forest ecosystems. When decisions are made, an important choice is made too (Tolunay and Korkmaz, 2004). In the permits necessary to build/construct any kind of facilities on forest areas in the name of public interest, it is expected and wanted that the developments/ investments will provide more benefits than the welfare provided by the forests. Otherwise, it should be accepted that the protection of forests as forests is a "superior public interest" (Gençay, 20I0). Superior public interest means a relatively comparative approach to different public benefits that may arise in many alternative uses/ situations, and to choose the one superior options, for sake of the public (Geray 2008). In a situation where there is a conflict of interest, it is often defined/explained/ expressed in the high court decisions-Constitutional Court, Court of Cassation, Council of State that of which benefit is the superior public interest in a given case in Turkey. However, depending on the nature of the case, it should not be forgotten that different decisions can be taken in different situations/scenarios by the high courts. It should/could be asked to the beneficiary community that in which benefit they see the superior public interest or the comparative advantages when there are two or more different activities/developments, so that the choice between the two benefits should be given. Because the main purpose of benefiting is the satisfaction and welfare of the community/society, and is the reason and ultimate goal of the existence of the concept of public interest. Improved concept of "public interest" are critical for ensuring that the regulatory framework for meaningful outcomes of sustainable development. 
Once and for all, as MacKenzie (2012) stated: Legislation alone will not prevent deforestation, but if properly used, law is an important tool in the fight against deforestation.

\section{REFERENCES}

AGRAWAL, A., CHHATRE, A., HARDIN, R. Changing governance of the world's forests, Science. v.320, n.5882, p. |460-| 462, 2008

ANTHON, L., GARCIA, S., STENGER, A. Incentive contracts for natura 2000 implementation in forest areas. Environmental and Resource Economics. v. 46, p. 28I302., 2010.

BIRBEN, Ü. Türkiye'de 1937 yılından sonra ormancilık mevzuatında yaşanan gelişmeler ve toplumsal yaşamla etkileşimler, İstanbul Üniversitesi Orman Fakültesi Dergisi, Seri:A, v.54, n. I, p. I-16, 2008.

BOX, C. R. Redescribing the public interest, The Social Science Journal, v.44, p.585-598, 2007

BOZEMAN, B., Public Values and Public Interest: Counterbalancing Economic Individualism, Georgetown University Press, ISBN 978-I-5890I-I77-9. USA. 2007.

CASSINELLI, C. W. Some Reflections on the Concept of the Public Interest, Ethics. v.69, n.I, p. 48-6I. 1958. http:// www.jstor.org/stable/2379439. (Access Date, 01.05.2018)

COŞKUN, A. A. Türkiye'de ormanlardan yararlanmanın yasal esasları, i.Ü. Orman Fakültesi Dergisi, Seri A, v.49, n.I, p.83-109.

CUMMINGS, L. S. Public Interest Law: The United States and Beyond, International Encyclopedia of the Social \& Behavioral Sciences, 2nd edition, p.555, Volume 19, ISBN: $9780080970875 \mathrm{v}, 2015$

DALTON, R., T., COATS, M., R., ASRABADI, R., B., 2005. Renewable resources, property-rights regimes and endogenous growth, Ecological Economics. v.52, n.l, p.3|-4I.

DOUGLAS, J., SIMULA, M. Global Forests: Debate and Dysfunction, Chapter 2, The Future of the World's Forests, pl9-39, $201 \mathrm{l}$.

EDWARDS, P., KLEINSCHMIT, D. Towards a European forest policy - Conflicting courses. Forest Policy and Economics. v.33, n.2013, p.87-93, 2013.

GANE, M. Forest Strategy Strategic Management and Sustainable Development for the Forest Sector, p444, Springer Netherlands, 2007.

GENÇAY, G.Ormancılıkta kamu yararı, Journal of the Faculty of Forestry. Istanbul University. v.60, p.38-49, 2010.
GERAY, U. Belek'te Golf Alanları ve Turizm Tesisleri İçin Tahsis Edilen Alanlar Konusunda Bir Değerlendirme ve Üstün Kamu Yararı, 2008 http://www.foresteconomics.org/ belekgeray.pdf (Access Date, 0I.03.20I7)

GIESSEN, L., KROTT, M., MÖLLMANN, T. Increasing representation of states by utilitarian as compared to environmental bureaucracies in international forest and forest-environmental policy negotiations, Forest Policy and Economics, v.38, p. 97-104, 2014.

GÜL, İ., 20I4. Danıştay kararlarında "kamu yararı" kavramı, Ankara Barosu Dergisi. v.2, n.23, p.534-550, 2014.

HADDAD, B.M. Property rights, ecosystem management, and John Locke's labor theory of ownership, Ecological Economics. v.46, n. I, p. 19-31, 2003.

HANSIS, R. A political ecology of picking: non-timber forest products in the pacific northwest, Human Ecology. v.26, n. I, p.67-86, 1998.

HENLEYN, D. Natural resource management: historical lessons from Indonesia. Human Ecology, v.36, p.273-290, 2008

JAGGER, P., LUCKERT, M., K., DUCHELLE E., A., LUND, F., J., SUNDERLIN, D., W. Tenure and forest income: observations from a global study on forests and poverty, World Development, v.64, n.I, p. 43-55, 2014.

KANT, S., BERRY, A., R. Institutions, Sustainability, and Natural Resources: Institutions for Sustainable Forest Management, Springer Netherlands, 2005

KOMORI, T. Regulation and Public Interests, The Possibility of Good Regulatory Government, Edt: Steven P. Croley, ISBN 978069| I 34642, 2007.

KROTT, M.Forest Policy Analysis, Springer Netherlands, 323p. 2005.

LANDSBERG, J., WARING, R. Forests in our changing world: new principles. Conservation and management, 2014.

MACKENZIE, C., P. Lessons from forestry for international environmental law, RECIEL, v.2।, n.2, p. II4-126.

MANTAU, U., WONG, L., G., J., CURL, S. Towards a taxonomy of forest goods and services, Small-scale Forestry. v. 6, p.39I-409, 2007.

NIE, M. The Governance of Western Public Lands: Mapping Its Present and Future. University Press of Kansas, ISBN 978-0-7006-1676-3, 2008.

NISKANEN, A., LUNNAN, A., OTA, I., BLATNER, K., HERBOHN, J., BULL, L., FERGUSON, I., HICKEY, M.G., Policies affecting forestry entrepreneurship. Small-scale Forestry. v.6, p.233-255, 2007.

NORTH, D., C. Institutions, Institutional Change, and Economic Performance, New York: Cambridge University Press. ISBN: 0-52 I-394I6-3, USA, 1990. 
OGM, Orman Genel Müdürlügüü 20 I I Yılı İdare Faaliyet Raporu, 490 s., Ankara, 2012.

OGM, Türkiye Orman Varlığı 20।5, Orman Genel Müdürlüğü, Ankara, 2015.

OGM, 2017. Ormancilık İstatistikleri 2016, Orman Genel Müdürlüğü, Ankara.

OWUBAH, E.C., LEMASTER, C.D., BOWKER, M. J., LEE, G.L. Forest tenure systems and sustainable forest management: the case of Ghana, Forest Ecology and Management, v. I49, n.I-3,p.253-264, 200 I.

PETERS, B., G. Governance as political theory, Critical Policy Studies, v.5, n. I, p.63-72, 201 I

POTEETE, A. R., OSTROM, E. Heterogeneity, Group Size and Collective Action: The Role of Institutions in Forest Management. Development and Change, v.35, p. 43546I, 2004.

PRICE, C., The Theory and Application of Forest Economics. 416p., Basil Blackwell, Oxford, 1989.

RAMETSTEINER, E. Governance concepts and their application in forest policy initiatives from global to local levels. Smallscale Forestry. v.8, p. I43-158, 2008

REKOSH, E. Who defines the public interest? Public interest law strategies in central and eastern Europe. Sur. Revista Internacional de Direitos Humanos. v.2, n.2, p.I74187, 2005.

RITTER, E., DAUKSTA, D. Human-forest relationships: ancient values in modern perspectives. Environ Dev Sustain. v. I5, p.645-662, 2013.

RODGERS, C. Property rights, land use and the rural environment: A case for reform, Land Use Policy, v.26, n.I, p.SI34-SI4I, 2009
SANDBERG, A. Property rights and ecosystem properties, Land Use Policy, v24, n.4, p.613-623, 2007.

SEYMOUR, F., FORWAND, E. Governing sustainable forest management in the new climate regime. Wiley Interdisciplinary Reviews: Climate Change. v.I, n.6, p.803-810, 2010.

SRIVASTAVA, N. Changing dynamics of forest regulation: coming full circle?, RECIEL. v.20, n. 2, p.II3-I22. ISSN $09628797,2011$.

TOLUNAY, A., KORKMAZ M. Ormancilıkta Kamu Yararı ve Üstün Kamu Yararı Üzerine Analizler, Süleyman Demirel Üniversitesi, Fen Bilimleri Enstitüsü Dergisi, v.8, n.(I), p.47-58, 2004.

TOULMIN, C. Securing land and property rights in sub-Saharan Africa: The role of local institutions, Land Use Policy, v.26, n. I, p. 10-19, 2009.

TUCKER, M., C., 1999. Private versus common property forests: forest conditions and tenure in a Honduran community. Human Ecology. v.27, n.2, p.20I-230,

VATN, A. Valuing Forest Ecosystems-An Institutional Perspective: Chapter 5, Kant, Shashi, Berry, R. Albert (Eds.), Institutions, Sustainability, and Natural Resources: Institutions for Sustainable Forest Management, pI I 5-I 34, 2005.

WHEELER, C. The Public Interest: We Know It's Important, But Do We Know What It Means, 2006. http://www.austlii. edu.au/au/journals/AIAdminLawF/2006/2.html, (Access Date, 0I.03.2018).

WIERSUM, K.F., ELANDS, B.H.M., HOOGSTRA, M.A., 2005. Small-scale forest ownership across Europe: Characteristics and future potential, Small-scale Forestry. v.4, n. I, p. I-19, 2005

ZIVNUSKA, J. A. Some aspects of the economic theory of forestry. Land Economics, v.25, n.2, p. 165-172, 1949. 